DOI: $10.19195 / 2084-5065.52 .2$

\title{
Crime victims' rights in the European area of justice and Polish legislation
}

\author{
JoANNA BeATA BANACH-GUTIERREZ \\ ORCID: 0000-0002-9705-7665 \\ Department of Security and Public Order \\ Faculty of Law and Administration \\ University of Warmia and Mazury in Olsztyn, Poland
}

\section{Introduction}

The human rights based approach is much dominates in contemporary criminal justice systems. The key aspects here are the privileged role for the procedural safeguards of suspects or defendants, while also taking into account the legal interests of victims. ${ }^{1}$ In other words, apart from the safeguards, which should be respected in regard to suspects (or defendants) in criminal proceedings, also more recognition has been recently given to the interests of crime victims. The procedural rights of, and assistance to, victims of crime are gradually becoming essential parts of con-

${ }^{1}$ E.g. A. Dearing, Justice for Victims of Crime: Human Dignity as the Foundation of Criminal Justice in Europe, Springer 2017; J.D. Mujuzi, "Victim participation in the criminal justice system in the European Union through private prosecutions: Issues emerging from the jurisprudence of the European Court of Human Rights," Eur.J.Cr.L.Cr.J24, 2016, no. 2, pp. 107-134, https://repository.uwc.ac.za/xmlui/bitstream/handle/10566/3832/Mujuzi_Victim-participation_2016.pdf?sequence=1\&isAllowed=y (accessed: 30.09.2019); The New Faces of Victimhood: Globalisation, Transnational Crimes and Victims Rights, eds. R. Letschert, J. Van Dijk, Springer 2011; M. Cherif Bassiouni, "International Recognition of Victims' Rights," [in:] International Criminal Law, ed. M. Cherif Bassiouni, third edition, Leiden 2008, pp. 636-701. 
temporary criminal justice systems, both at the global and regional levels. This seems to be a very important question, particularly in the context of trans-European criminal proceedings within European Union territory. ${ }^{2}$

In the region of Europe, the right to a fair trial is reflected in Article 6 of the European Convention on Human Rights (ECHR), and Article 47 of the EU Charter of Fundamental Rights (CFR). Within the European Union, this is however the Lisbon Treaty which introduced fundamental rights at the forefront of the Treaty on the European Union (Article 2 TEU) and binding status of the EU Charter of Fundamental Rights (Article 6 (1) TFUE). The greatest distinction between the CFR and the ECHR in the field of criminal justice is not only the recognition of the rights of suspects in the trial, but also the rights of other participants in the course of criminal proceedings. ${ }^{3}$

Referring to crime victims, there are such relevant provisions covered in the CFR, as human dignity (Article 1), right to life (Article 2), right to the integrity of the person (Article 3), prohibition of torture and inhuman or degrading treatment or punishment (Article 4), prohibition of slavery and forced labour (Article 5), right to liberty and security (Article 6), re-

2 Report (2014): Victims of crime in the EU: the extent and nature of support for victims, FRA-European Union agency for Fundamental Rights, https://fra.europa.eu/sites/ default/files/fra-2015-victims-crime-eu-support_en_0.pdf(accessed: 30.09.2019); Report on the standing and rights of victims in criminal proceedings, prepared by Mr Brano Bohacik, European Committee on Crime Problems (CDPC), Strasbourg, 20 September 2010, https://rm.coe.int/168070c7e4 (accessed: 30.09.2019); J. Blackstock, Protecting Victims: EU competences and mechanisms for safeguards. Paper presented at the Symposium: 'Legal Perspectives on the Victims', Nottingham Trent University, 19 December 2012, http://2bquk8cdew6192tsu41lay8t.wpengine.netdna-cdn.com/wp-content/ uploads/2015/02/Protecting-Victims-EU-Competences-and-mechanisms-for-safeguards. pdf (accessed: 30.09.2019).

3 E.g. Victims and Criminal Justice. European Standards and National Good Practices, ed. L. Luparia, Wolters Kluwer 2015; Protecting Vulnerable Groups. The European Human Rights Framework, eds. F. Ippolito, S. Iglesias Sánchez, Oxford 2015; Human Rights in European Criminal Law: New Developments in the European Legislation and Case Law After the Lisbon Treaty, ed. S. Ruggeri, Springer 2015; Victims and Restorative Justice, eds. I. Vanfraechem, D. Bolivar, I. Aertsen, London-Routledge 2015; A. Pemberton, M. Groenhuijsen, "Developing Victims' Rights within the European Union. Past, Present and Future," [in:] Victimology and Human Security: New Horizons, eds. H. Morosawa, J.P. Dussich, G.F. Kirchoff, Nijmegen 2012. 
spect for private and family life (Article 7), protection of personal data (Article 8), equality before the law (Article 20), non-discrimination (Article 21), right to an effective remedy and to a fair trial (Article 47). It is argued that creating a European area of justice requires more attention, both to the procedural safeguards of the suspects (defendants) and to the rights of victims. ${ }^{4}$

Both Council Framework Decision 2001/220/JHA of 15 March 2001 on the standing of victims in criminal proceedings (hereafter, the Council FD of 2001) $)^{5}$ and Directive 2012/29/EU of the European Parliament and of the Council of 25 October 2012 establishing minimum standards on the rights, support and protection of victims of crime, and replacing Council Framework Decision 2001/220/JHA (hereafter, the Victims' Directive) ${ }^{6}$ are illustrative for a new direction in strengthening crime victims' rights. The Council FD of 2001 was in comparison to the previous Council of Europe Recommendations, ${ }^{7}$ no longer "soft law," but a binding EU legal

4 E.g. St. Trechsel, Sarah J. Summers, Human Rights in Criminal Proceedings, Oxford 2005, pp. 36-42; S. van der Aa et al., Project Victims in Europe: Implementation of the EU Framework Decision on the standing of victims in the criminal proceedings in the Member States of the European Union, Lisbon 2009, https:/cris.maastrichtuniversity.nl/ portal/en/publications/project-victims-in-europe-implementation-of-the-eu-frameworkdecision-on-the-standing-of-victims-in-criminal-proceedings-in-the-member-states-ofthe-european-union(c0faf87e-e27c-43a1-9e11-5bb82466eb0c)/export.html (accessed: 30.09.2019); Victims and Corporations: Legal Challenges and Empirical Findings, eds. G. Forti et al., Milano-Padova 2018, https://asgp.unicatt.it/asgp-VictimsCorporations Ebook_2018.pdf (accessed: 30.09.2019); Handbook for Implementation of Legislation and Best Practice for Victims of Crime in Europe, Victim Support Europe 2013, http:// victimsupporteurope.eu/activeapp/wp-content/files_mf/1385974688NewVersionVSEHa ndbookforImplementation.pdf (accessed: 30.09.2019).

5 OJ L 82, 22.3.2001, pp. 1-4.

6 OJ L 315, 14.11.2012, pp. 57-73. This Directive was adopted on 25 October 2012, and came into force on 15 November 2012. The EU Member States were obligated to implement its provisions into their national laws by 16 November 2015. DG Justice of the Commission issued a Guidance Document of December 2013 related to the transposition and implementation of the Directive 2012/29/EU in order to assist Member States in this process.

7 Specifically, the Committee of Ministers Recommendation Rec (2006) 8 on assistance to crime victims which contains a definition of "victim" consistent with that provided for in the EU Framework Decision 2001/220/JHA of 15 March 2001 on the standing of victims in criminal proceedings. 
instrument. Furthermore, under the Victims' Directive, the victims of crime are even formally entitled to exercises their legal rights in a more direct way. Namely, this Directive is a binding EU Member States legal instrument (EU secondary legislation), which for the first time established a certain kind of uniform catalogue of victims' rights. ${ }^{8}$

However, it is argued that despite adopting the Victims' Directive, still making victims' rights truly effective at the Union level remains a big challenge. As Ivo Aertsen argues, in order to improve the status of victims, there is a real need for legal reforms in EU Member States, and within their criminal justice systems themselves. Also, for implementation of victims' rights, this is necessary to take into account a sociological context, for example citizens' perceptions and opinions about crime and the role of the criminal justice system in society, the relationship of justice processes to other types of interventions and remedies, and in general the social, cultural, economic and personal conditions in a given country. ${ }^{9}$

\section{Towards more fairness for crime victims in criminal proceedings}

To briefly recall, the discussed question regarding crime victims' rights was a subject of debate during the European Council Meeting held in Tampere, 1999. Its Presidency Conclusions, in point 32 directly calls for some minimum standards, which "should be drawn up on the protection of victims of crime, in particular on a crime victim's access to justice and on their rights to compensation for damages, including legal costs. In addition, national programmes should be set up to finance measures, public and non-governmental, for assistance to and protection of victims." The first bigger step towards more fairness for crime victims in criminal

8 The Directive shall be binding, as to the result to be achieved, upon each Member State to which it is addressed, but shall leave to the national authorities the choice of form and methods (Article 288 of the Treaty on the Functioning of the European Union).

9 I. Aertsen, "Victims' Rights: an Overview," [in:] Rights of Victims, Challenges for Corporations: Project's First Findings, ed. C. Mazzucato, Milano 2016, pp. 2-7; http://www.victimsandcorporations.eu/ (accessed: 20.12.2017). 
proceedings is without any doubt the Council FD of 2001, with a view to harmonising their granted rights within the European Union. ${ }^{10}$

However, judicial practice under the regime of the Council FD of 2001 proved that as so far in many Member States the regulations on crime victims' rights had not been properly implemented into their national legislation. Such a situation in its natural way had to lead to concerns about the weaker position of crime victims in comparison with the status of suspects or accused persons in criminal proceedings. ${ }^{11}$ Therefore, the Council FD of 2001 was subsequently replaced by adopting the Victims' Directive. In comparison with the Council FD of 2001, this new legal instrument contains more concrete rights for victims and clearer obligations for EU Member States. One should notice that besides legal instruments, there is a visible reflection of crime victims' rights approach in the jurisprudence of the CJEU as well. ${ }^{12}$ Also, one should remember that an appropriate place of victims in the European area of justice has found its legitimate confirmation in Article 82 (2) TFEU.

\section{The Victims' Directive: What are the main purposes and contents?}

The Victims' Directive indicates the various measures, which may be catalogued, as the following: (1) provision of information and support (CHAPTER 2, Articles 3-9); (2) participation in criminal proceedings (CHAPTER 3, Articles 10-17); (3) protection of victims and recognition of victims (CHAPTER 4, Articles 18-24); (4) other provisions (CHAPTER 5, Articles 25-26). Generally speaking, this Directive serves a double purpose. Firstly, it aims to ensure that crime victims shall receive appro-

10 M. Fichera, "The Status of the Victim in European Union Criminal Law," Eucrim 2011, no. 2, pp. 79-81.

11 M.S. Groenhuijsen, A. Pemberton, "The EU Framework Decision for Victims of Crime: Does Hard Law Make a Difference?” Eur.J.Cr.L.Cr.J 17, 2009, no. 1, pp. 43-59.

12 E.g. Criminal proceedings against Maria Pupino, Case Number C-105/03, Date of the judgement 2005-06-16, Court of Justice (ECJ); Criminal proceedings against X C-507/10, Case Number C-507/10, Date of the judgement 2011-12-21, Court of Justice (ECJ); Gueye and Salmerón Sánchez, Joined cases C-483/09 and C-1/10, Date of the judgement 2011-09-15, Court of Justice (ECJ). 
priate information, support and protection throughout the EU (with the exception of Denmark ${ }^{13}$ ); Secondly, it seeks to ensure that crime victims are able to participate in criminal proceedings (Article 1 (1)). Here, one may share the opinion that EU Member States should recognise the victim as an individual with individual needs, with a key role in criminal proceedings, while respecting the fair trial principle and without prejudice to the rights of the offender. ${ }^{14}$

What is much more important, is that DG Justice issued a Guidance Document of 2013 to facilitate the effective and timely transposition of the Victims' Directive by the EU Member States that are bound by its provisions. In accordance with DG Justice Guidance, the general principles of EU law (for instance equality and non-discrimination) and the provisions of the CFR must be fully respected. Also, the existing case-law standards of the European Court of Human Rights which contains various references to crime victims' rights, in particular as regards the access to justice and respect of due process requirements are binding. ${ }^{15}$ In addition, Member States should take into account a number of international standards on crime victims' protection that have been developed along with the passing years by the United Nations and by the Council of Europe. ${ }^{16}$

13 Only Denmark did not sign up to this Directive, as Denmark does not sign up to any justice and home affairs issues. Therefore Denmark is not obliged to participate in the application of the 'Victims' Directive'.

14 E.M. Mancuso, "“Victims' Participation in Criminal Proceedings," [in:] Rights of Victims..., pp. 2-3, 27. Compare: E.M. Mancuso, "The role of victims of corporate violence within criminal proceedings: current status and future perspectives", [in:] Victims and Corporations..., pp. 69-84.

15 Perez v. France [GC], 47287/99, 12 February 2004; Gorou v. Greece (N²) [GC], 12686/03, 20 March 2009; Ernst and Others v. Belgium, 33400/96, 15 July 2003; Sottani v. Italy, 26775/02, 24 February 2005; See further: Report on the standing and rights of victims in criminal proceedings, prepared by Mr. Brano Bohacik, European Committee on Crime Problems (CDPC), Strasbourg, 20 September 2010, https://rm.coe. int/168070c7e4 (accessed: 17.12.2017).

16 DG Justice Guidance Document of December 2013 related to the transposition and implementation of Directive 2012/29/EU of the European Parliament and of the Council of 25 October 2012 establishing minimum standards on the rights, support and protection of victims of crime, and replacing Council Framework Decision 2001/220/ JHA, http://ec.europa.eu/justice/criminal/files/victims/guidance_victims_rights_directive_en.pdf (accessed: 25.12.2019). 
The definition of victim is laid down in Article 2 paragraph 1 (a) (i) of the Directive, according to which a victim is: "a natural person who has suffered harm, including physical, mental or emotional harm or economic loss which was directly caused by a criminal offence." This main category of victims is extended, by a derivative form of victimhood that means, covering in paragraph 1 (a) (ii) family members of the deceased victim who have suffered harm because of a person's death directly caused by a criminal offence. According to the DG Justice Guidance Document the criterion "harm" should be interpreted in the context of the individual emotional relationship and/or direct material inter-dependence between the deceased victim and the relative(s) concerned. Further, the Directive provides in paragraph 1 (b) that "“family members' means the spouse, the person who is living with the victim in a committed intimate relationship, in a joint household and on a stable and continuous basis, the relatives in direct line, the siblings and the dependants of the victim."17

The Victims' Directive requires all Member States to ensure that victims receive standardised information across the EU on such rights as: the right to understand and to be understood (Article 3); right to receive information from the first contact with a competent authority (Article 4); right of victims when making a complaint (Article 5); right to receive information about their case (Article 6); right to interpretation and translation (Article 7); right to access victim support services (Article 8); right to support from victim support services (Article 9); right to be heard (Article 10); rights in the event of a decision not to prosecute (Article 11); right to safeguards in the context of restorative justice services (Article 12); right to legal aid (Article 13); right to reimbursement of expenses (Article 14); right to the return of property (Article 15); right to decision on compensation from the offender in the course of criminal proceedings (Article 16); rights of victims resident in another Member State (Article 17); right to protection (Article 18); right to avoid contact between victim and offender (Article 19); right to protection of victims during criminal investigations

17 See further: Criminal proceedings against Giovanni Dell'Orto, Case Number C-467/05, Date of the judgment 2007-06-28, Court of Justice of the European Communities (ECEJ); Criminal proceedings against Emil Eredics and Mária Vassné Sápi. Case Number C-205/09, Date of the judgement 2010-10-21, Court of Justice of the European Communities (ECEJ). 
(Article 20); right to protection of privacy (Article 21); individual assessment of victims to identify specific protection needs (Article 22); right to protection of victims with specific protection needs during criminal proceedings (Article 23); right to protection of child victims during criminal proceedings (Article 24). Consequently the Victims' Directive is tending to the approximation of national legislation and practices on protection of victims, during all stages of the criminal proceedings. So, this Directive brings a really significant added value, since it contains some concrete and comprehensive rights for victims of crime and also clear obligations for EU Member States. ${ }^{18}$

Here, a very important issue is the specific treatment of so - called vulnerable victims, particularly children. In reference to child victims, there is a presumption that all child victims need special protection measures. Children are always presumed to be vulnerable. ${ }^{19}$ The needs of victims can be grouped in the five main categories, which are reflected in the Victims' Directive (1) recognition and respect (respectful treatment); (2) protection; (3) support; (4) access to justice; (5) compensation and restoration. ${ }^{20}$

\subsection{Recognition and respect}

The Victims' Directive provides for the rights of recognition and respectful treatment in article 1(1), that is: "Member States shall ensure that victims are recognised and treated in a respectful, sensitive, tailored, professional and non-discriminatory manner, in all contacts with victim

18 A. Klip, European criminal law, Intersentia 2016, pp. 323-334; V. Mitsilegas, EU criminal law after Lisbon: Rights, Trust, the Transformation of Justice in Europe, Hart Publishing-Bloomsbury Collections 2016, pp. 185-211.

19 Compare: Recommendation CM/Rec (2012) 2 of the Committee of Ministers to member States on the participation of children and young people under the age of 18 (Adopted by the Committee of Ministers on 28 March 2012 at the 1138th meeting of the Ministers' Deputies), https://rm.coe.int/168046c478 (accessed: 19.12.2017).

20 DG Justice Guidance Document of December 2013, note above; Rights of the victim, http://ec.europa.eu/justice/criminal/victims/rights/index_en.htm (accessed: 19.12.2017). Claudia Mazzucato mentions the following list: recognition of vulnerability and/or of specific protection needs; respect; information; support; protection; access to justice and participation in criminal proceedings; access to compensation and restoration, see: C. Mazzucato, "Victims in the European Union and Directive 2012/29/EU," [in:] Rights of Victims..., pp. 18-19. 
support or restorative justice services or a competent authority, operating within the context of criminal proceedings. The rights set out in this Directive shall apply to victims in a non-discriminatory manner, including with respect to their residence status." Further, article 3 clarifies "communication safeguards" in detail. Accordingly, this requires Member States to take appropriate measures to assist victims to understand and to be understood from first contact and during any further necessary interaction they have with a competent authority in the course of criminal proceedings. This includes the provision of information in simple and accessible language (orally or in writing) for their means, and to allow them to be accompanied by someone where this is necessary to aid comprehension.

There should be demonstrable efforts to provide information in a child-friendly manner if a child is involved. Such a new "personalised approach" taken in the Directive underlines the individual victim's ability to "follow the proceedings." In brief, the Directive seeks to ensure that victims - based on their personal characteristics (e.g. gender, disability, age, maturity, relationship to or dependence on the offender) understand and can make themselves understood during criminal proceedings (linguistically or otherwise) and that authorities pro-actively assist victims to do so throughout criminal proceedings. Article 4 requires Member States to ensure that victims are offered the specific and detailed information, without unnecessary delay, from their first contact with a competent authority in order to enable them to access the rights set out in this Directive. In other words, article 4 establishes a "right for victims to receive information." The rationale behind this provision requires the criminal justice authorities to provide extensive information proactively ex officio, rather than the onus being on victims to seek out such information for themselves. Victims must be granted "effective access to information." This information concerns how and in what circumstances they can access: support and any relevant specialist support; procedures for making complaints; protection measures; legal advice, legal aid and any other sort of advice; compensation; interpretation and translation; services (any special measures, procedures or arrangements) where the crime occurs in a country they are not resident in; the contact details for communications about their case; restorative justice services; reimbursement of expenses. 
Article 5 provides new rights for when victims make a complaint. Such a complaint may be made either orally or in writing, by various means (e.g. at a local police station, by telephone, text message or online). The Article requires the authorities to provide the victim with at least a written acknowledgment that a formal complaint has been made, containing the basic elements of the criminal offence. The introduced mechanism for making a complaint, includes the requirement to provide a written acknowledgment and interpretation or translation services, free of charge, to facilitate the process. Article 6 provides the right to receive information about their case. All victims must be notified of their right to receive information related to (a) a decision to end criminal proceedings (including the reasons for this) and (b) the time and place of the trial and the nature of the charges. Once they are aware of such rights, victims can then receive such information if they so request.

Moreover, only victims with a "role" in the relevant criminal justice system have to be notified of their rights to receive (a) the final judgment (and its reasons) and (b) information about the state of criminal proceedings (unless this would adversely affect the case). Information can be communicated to the victim orally or in writing, including through electronic means, to the last known correspondence or e-mail address. Also, the reasons or a brief summary of reasons for the above-mentioned decisions to end proceedings (i.e. not to proceed with or to end investigations or not to prosecute the offender) or the final judgment must be provided. As an exception to this rule, the reasons for a jury decision or a decision where the reasons are confidential as a matter of national law do not have to be disclosed.

It is emphasized in a DG Justice Guidance Document that: "Giving victims reasoned decisions is important to allow victims to access justice. Moreover, it is also a basic form of respect and recognition of the victim. In addition, the right of victims to review a decision not to prosecute in Article 11 would not be effective without proper knowledge of the facts leading to a contested decision. Giving victims complete information also helps to reduce the administrative burden of following proceedings as it makes it less likely that victims might come back repeatedly seeking answers to their questions." 21

21 DG Justice Guidance Document of December 2013, note above, p. 19. 


\subsection{Protection}

Article 6, paragraph 5 of the Directive requires that all victims must be "offered the opportunity to be notified" of the offender's release or escape from detention and any protection measures available. Paragraph 6 deals with receiving such notifications if requested at least when there is danger or identified risk of harm to the victim, unless there is an identified risk of harm to the offender as a result. Considering that the offender may be released or escape from arrest, this means in practice that the victim should be informed of their right to be notified of the offender's escape or release as from the first contact with the competent authority and thereafter at any relevant stage of the proceedings. This includes notifying the victim if there is a sentence of imprisonment. Whether the victim requests such notification at that first contact or at any time during or after the proceedings, the request should be binding on the competent authorities and the information requested should be submitted to the victim without unnecessary delay.

The victim also has the right to be informed of applicable protection measures in line with the individual and risk assessment that the authorities carry out. As the offender may be at risk of reprisal (and may thus also need protection), the authorities must, on a case-by-case basis, strike a proper balance between the safety of both the offender and the victim when applying this provision. However, the Directive does not introduce the right for victims to lodge an appeal against a decision on releasing the offender, nor the right to be heard in the release procedure before the competent authorities. Extending victims' procedural participation in the decision-making process on release remains a matter for national discretion, taking due account of provisions of the European Convention on Human Rights (ECHR) from the victims' rights perspective. Chapter 4 provides for protection of victims and recognition of victims with specific protection needs. ${ }^{22}$

22 Claudia Mazzucato indicates that in international and European legal documents the following are often quoted as persons in need of specific protection: children, women, the elderly, people with disabilities, victims of crimes occurring in a country of which they are not nationals or residents, victims of gender-based violence, victims of violence in close relationships and domestic violence, victims of sexual violence and other sexual offences. Victims of trafficking in human beings, victims of terrorism, victims 
In Article 18 Member States are obligated without prejudice to the rights of the defence to ensure that measures are available to protect victims from secondary and repeat victimisation, ${ }^{23}$ from intimidation and from retaliation, including against the risk of emotional or psychological harm, and to protect the dignity of victims during questioning and when testifying. ${ }^{24}$ When necessary, such measures should also include procedures established under national law for the physical protection of victims. The measure extends to family members, too. These measures (such as interim injunctions or protection/restraining orders) have to be issued with a view to protecting a person when there are serious grounds for considering that that person's life, physical or psychological integrity, personal liberty, security or sexual integrity is at risk. What is important, the matter of domestic protection measures is not explicitly dealt with by the Directive. Thus, as laid down in the DG Justice Guidance Document "Article 18 does not harmonise the types of national protection orders.

However, Article 5 of the Directive 2011/99/EU on the European Protection Order ('EPO Directive') and Article 3(1) of the Regulation $606 / 2013 / \mathrm{EU}$ on the mutual recognition of protection measures in civil matters ('EPO Civil Regulation') could be used as guidance as to what should be deemed as a minimum (i.e. (a) prohibition from entering certain localities, places or defined areas where the protected person resides or visits; (b) prohibition or regulation of contact, in any form, with the protected person; (c) prohibition or regulation on approaching the protected person more closely than a prescribed distance)." 25 The EPO Directive and the EPO Civil Regulation require Member States to ensure the mutual recognition of protection measures issued in another Member State.

of organised crime, victims of crimes committed with a bias or discriminatory motive. See: C. Mazzucato, "Victims in the European Union...," p. 12. Compare: C. Mazzucato, "Victims of corporate violence in the European Union: challenges for criminal justice and potentials for European policy," [in:] Victims and Corporations..., pp. 22-60.

23 E.g. J-A. Wemmers, "Victims' experiences in the criminal justice system and their recovery from crime," International Review of Victimology 19, 2013, no. 5, pp. 221233.

24 E.g. S. Maffei, The European Right to Confrontation in Criminal Proceeding. Absent, Anonymous and Vulnerable Witnesses, Groningen 2006, p. 53.

25 DG Justice Guidance Document of December 2013, note above, p. 40. 
Article 19 requires Member States to take measures to avoid contact between victim and offender. The contact should be avoided in all premises involved in criminal proceedings (i.e. including police stations, prosecutors' offices and court premises) and that all new court premises have to designate separate waiting areas for victims. The court room itself should be designed to avoid the victim/witness having to walk in front of the accused or any associated friends/family to get to the witness box, as this may increase the victim/witness's sense of feeling threatened or intimidated. The exception of "unless the criminal proceedings require such contact" should be interpreted strictly proportionately meaning that the victim's interests are secondary to the interests of proceedings.

The purpose of Article 20 is to prevent secondary victimisation of all victims - not just vulnerable victims. It is argued that treating victims properly during criminal investigations should be a basic element of good administration of justice. Thus, victims should be interviewed as early as possible and interaction with authorities should be as easy as possible, while limiting the number of unnecessary interactions the victim has with them. Interviews and medical examinations should be kept to a minimum and only be conducted where strictly necessary for the purposes of the criminal proceedings. In addition, the right to be accompanied by a person of choice in Article 20, paragraph 2 (c) applies to all victims (not just to vulnerable or child victims). If the victim has a legal representative, this lawyer should be present at interviews. Article 21, in turn, covers the requirement to protect the privacy of victims and their family members, specifically to avoid their secondary victimisation. Therefore, Member States should encourage the media to take self-regulatory measures on ethical conduct towards victims. Criminal law measures against individuals who violate privacy protection rules should also be considered. Furthermore, in the interests of child victims, the competent authorities must prevent information that could lead to their identification being publicly disseminated. But, the identification of a child victim in exceptional cases may be necessary, and in the interests of his or her safety and for this reason should be allowed. The provisions of Article 22 are one of the major achievements in the Victims' Directive. This includes the obligation for Member States to ensure that victims receive a timely and individual assessment, in accordance with national procedures, to identify specific 
protection needs. ${ }^{26}$ Children are always presumed to have specific protection needs due to their vulnerability to secondary and repeat victimisation, to intimidation and to retaliation. So, they should be subject to an individual assessment, as a rule. It is stressed that the assessment for children would thus consist of determining which of the protection measures listed in Articles 23 and 24 of the Directive would need to be put in place for each individual child. Children's Home or child protection centres with an integrated and multidisciplinary approach are particularly well placed to conduct such individual assessments. Article 23 provides for special protection measures to be available where individual assessment has determined such a need. ${ }^{27}$ In these cases, victims with specific needs should benefit from special protection measures listed in this Article, as determined in the "second step" of the individual assessment established in Article 22. Whether a victim with specific needs should benefit from some or all of these measures is, thus, determined in the individual assessment (taking into account the victim's wishes).

Finally, Article 24 deals with the protection of child victims during criminal proceedings. This reflects the current approach towards child victims of crime. Accordingly, in addition to the protection measures listed in Article 23, the specific measures listed in Article 24 apply to child

26 Special attention is given to the support and protection of victims of certain crimes, for instance gender-based violence. The Directive also insists on a child-sensitive approach, whereby the best interests of a child victim must be the primary consideration throughout their involvement in criminal proceedings. The Member States should rely on the Guidelines of the Council of Europe on child - friendly justice "to ensure that all rights of children involved in judicial proceedings are fully respected with due consideration to the child's level of maturity and understanding," see: DG Justice Guidance Document of December 2013, note above, p. 4, 8. Joined cases C-483/09 and C-1/10 Gueye and Salmerón Sánchez, Date of the judgment 2011-09-15, Court of Justice (ECJ). Case Number C-507/10 Criminal proceedings against X, Date of the judgment 2011-12-21,Court of Justice (ECJ).

27 Claudia Mazzucato stresses that the Victims' Directive "focuses the attention on an individualised and personalised comprehensive approach in which the individual's 'protection needs' must be singularly assessed and taken into account. This assessment must guide competent authorities (police and judicial authorities) and victims support services dealing with victims case by case, and in offering them the most adequate and tailored protection, assistance, support." See: C. Mazzucato, "Victims in the European Union...," p. 16. 
victims, in line with the child-sensitive character of this Directive. All of these measures are included in the Human Trafficking and Child Sexual Exploitation Directives. ${ }^{28}$ Member States have to ensure that measures to protect child victims shall be adopted in their best interests, taking into account an assessment of their needs. In this respect, they should consider two main questions: firstly, how to ensure that the best interests and needs of the child victim are a primary consideration throughout the victim's interaction with the criminal justice system, if necessary by reviewing their national criminal justice system; ensuring that professionals working with child victims receive specialised training in how to communicate with young victims of crime and how to identify and limit the risk of "revictimisation" (as provided in Article 25). Secondly, the adjusting and modernising police, prosecutor and court facilities to enable the smooth application of listed measures. This may include the set-up of an adequate video conferencing system to use when interviewing children. ${ }^{29}$

\subsection{Support}

Article 7 of the Victims' Directive provides a right to interpretation for interviews or questioning and for hearings, and also a right to translation of all essential information, free of charge. Both a right to interpretation and translation shall be applied only to victims with a formal role in proceedings - "in accordance with their role in the relevant criminal justice system in criminal proceedings." Interpretation and translation must be given on request, i.e. the victim must have expressed the wish to receive interpretation or translation. Here, Member States should consider establishing videoconferencing and other technological tools that may be used to ensure victims can access interpretation and translation as and when required (modern communication technology). In practice, this means that for instance, the police may call an interpreter by phone if urgently needed. The purpose of Article 8 is to ensure that victims (and to some extent their families) have access to confidential victim support services, free of charge, acting in the interests of the victims before, during and

28 Directive 2011/36/EU of the European Parliament and of the Council of 5 April 2011 on preventing and combating trafficking in human beings and protecting its victims, and replacing Council Framework Decision 2002/629/JHA, OJ L 101, 15.4.2011, pp. 1-11.

29 DG Justice Guidance Document..., note above, pp. 40-48. 
for an appropriate time after criminal proceedings. These may include information and advice, emotional and psychological support and practical assistance. The right to support is one of the core victims' rights in the Directive. Proper support is essential for the victim's recovery. It is truly noticed that support should be available from the earliest possible moment after a crime has been committed, irrespective of whether it has been reported.

Support will be valuable, for example, if medical treatment is ongoing due to the severe physical or psychological consequences of the crime, or if the victim's safety is at risk due to their statements during criminal proceedings. This Article also requires Member States to facilitate referrals of victims (most often from the police) to victim support organisations (VSOs) by the competent authority that received the complaint or by other relevant entities. Referrals "by other relevant entities" in contact with victims of crime may include hospitals, schools, embassies, consulates, welfare or employment services, who are in contact with victims and identify the need for the victim to seek the specialised services of a VSO. Some victims of crime (victims of sexual violence, violence in close relationships, victims of hate crime or human trafficking) require specialist support due to their personal vulnerability or particular circumstances or the nature of the crime.

Access to any victim support services must not be dependent upon the making of a formal allegation. Article 9 dealing with support from victim support services is to be read in conjunction with Article 8. It provides a specific list of general and specialist support services as a minimum requirement. These are: "(a) information, advice and support relevant to the rights of victims including on accessing national compensation schemes for criminal injuries, and on their role in criminal proceedings including preparation for attendance at the trial; (b) information about or direct referral to any relevant specialist support services in place; (c) emotional and, where available, psychological support; (d) advice relating to financial and practical issues arising from the crime; (e) unless otherwise provided by other public or private services, advice relating to the risk and prevention of secondary and repeat victimisation, of intimidation and of retaliation." Specialist support services, unless provided elsewhere, must as a minimum, develop and provide shelters or any other interim accom- 
modation when victims need a safe place to prevent victimisation, and trauma support and counseling. The various types of specialised services should reflect optimally the individual approach to every victim, taking into account the nature and severity of the crime.

Specialist support may be provided by both public and private services (for example medical establishments, health and psychiatric entities or social services). In addition, “an 'integrated' approach when providing victim support should take into account the relationship between victims, perpetrators, children and their wider social environment to avoid the risk of assessing their needs in isolation or without acknowledging their social reality. Thus, when providing targeted, integrated support, it is important to ensure that the needs of victims are assessed in the light of all relevant circumstances to allow professionals to take properly informed, appropriate decisions." 30

\subsection{Access to Justice}

Chapter three of the Victims' Directive concerns the participation in criminal proceedings. Article 10 provides a right to be heard and to provide evidence during criminal proceedings. The purpose of Article 10 is to ensure that all victims have an opportunity to provide information, views or evidence throughout criminal proceedings. ${ }^{31}$ In the event, if a child victim is to be heard, due account shall be taken of the child's age and maturity. ${ }^{32}$ The issue of the applicable procedural rules is left to national law. At this point, one should stress that the principles of judicial discretion and free assessment of evidence must be preserved. In turn, Article 11 requires that victims, in accordance with their role in the relevant criminal justice system, have the right to a review of a decision not to prosecute. As clarified in the DG Justice Guidance Document, the purpose of this Article is to enable the victim to verify that established procedures and rules have been complied with and that a correct decision has been made to end a prosecution in relation to a suspected person. Furthermore, the

30 DG Justice Guidance Document of December 2013..., note above, pp. 21-29.

31 See, also: György Katz v István Roland Sós, Case number C-404/07, Date of the judgment 2008-10-09, Court of Justice of the European Communities (ECEJ).

32 Criminal proceedings against Maria Pupino, Case C-105/03, Judgment of the Court (Grand Chamber) of 16 June 2005. 
Directive respects national procedural autonomy and does not harmonise the relations of subordinations among authorities. Therefore, precise modalities of such a mechanism for a review are left to national law. ${ }^{33}$

Next, Article 13 imposes a concrete obligation on the Member States to enable victims their right to legal aid. It states that victims should have "access to legal aid, where they have the status of parties to criminal proceedings. The conditions or procedural rules under which victims have access to legal aid shall be determined by national law." So, national law must provide for the appropriate legal framework to ensure that victims have the right to legal aid. In the event if a victim has the right to access legal aid under national law, it should at least cover legal advice and legal representation free of charge. One should also pay attention to the meaning of Article 17 because it provides cross-border rights to victims. In this sense, this is one of the more innovative paragraphs. So, a victim resident in a Member State other than where the offence was committed has the same rights and it is the Member States' obligation to minimise the difficulties arising from that situation. ${ }^{34}$

\subsection{Compensation and Restoration}

The Directive provides respectively the following rights: right to reimbursement of expenses at Article 14, right to the return of property at Article 15 and right to decision on compensation from the offender in the course of criminal proceedings at Article 16. It is explained that "the purpose of Article 14 is to ensure that victims are not prevented from actively participating in criminal proceedings - and thus seeing justice done- due to their own financial limitations." 35 In practice, such necessary expenses will include travel expenses and loss of earnings. In reference to the return of property under Article 15, this is national law which determines the conditions or procedural rules under which such property is returned

33 DG Justice Guidance Document..., note above, pp. 29-30.

34 See also: Directive 2014/41/EU of the European Parliament and of the Council of 3 April 2014 regarding the European Investigation Order in criminal matters, OJ L $130,1.5 .2014$, pp. 1-36. It provides for hearing by videoconference or other audiovisual transmission (Article 24) and hearing by telephone conference (Article 25).

35 DG Justice Guidance Document..., note above, p. 35. 
to the victims. According to the DG Justice Guidance Document, the return of property should be free of charge for the victim. Costs related to returning property should be borne by the State.

Also, Member States should consider where appropriate, developing an effective administration procedure whereby victims can ask to have their property returned sooner under certain circumstances. For instance, this might be applicable when an investigation is closed or a prosecutor decides not to prosecute the case, or else in the event of taking a copy of the relevant information in the victims' mobile phone, computer containing evidence, etc. Article 16, in turn, requires Member States to ensure that, in the course of criminal proceedings, victims are entitled to obtain a decision on compensation by the offender, within a reasonable time, except where national law provides for such a decision to be made in other legal proceedings. What is more, Member States are also asked to encourage offenders to provide adequate compensation to victims. Here, one should notice that if the victim is claiming compensation from the offender outside the criminal proceedings, for instance, through a separate civil claim, the exclusion in the Article applies. What is important, this Article only deals with compensation from the offender, and not from the State. ${ }^{36}$ It is stressed in the DG Justice Guidance Document that "pursuant to Article 4, paragraph 1(e), information about how and under what conditions victims can access compensation (i.e. from all available compensation schemes ${ }^{37}$ ) must be provided at first contact with competent authorities. In addition, victim support services must provide information on accessing national compensation schemes for criminal injuries under Article 9, paragraph 1(a)." Another crucial question is about restorative justice. For the first time in EU criminal law, the Victims' Directive deals extensively with restorative justice that is reflected in Article $12 .{ }^{38}$

36 Compare: Case Number C-79/11, Criminal proceedings against Maurizio Giovanardi and Others, Date of the judgment 2012-07-12, Court of Justice (ECJ).

37 Cross- border state compensation claims are governed by the Directive 2004/80/ EC relating to compensation to crime victims, OJ L 261, 6.8.2004, pp. 15-18.

38 See , also: I. Aertsen, "Restorative justice for victims of corporate violence," [in:] Victims and Corporations..., pp. 235-253. 


\section{Polish legislation on crime victims' rights vis-à-vis the European area of justice}

In Poland, the key guidelines for the proper treatment of crime victims have been gradually developed through the jurisprudence of Courts. In addition, an important role is played by NGOs. The Polish Charter of Victims' Rights (1999) provides such rights as a right to receive assistance; a right to dignity, respect, and compassion; a right to security and freedom from secondary victimisation; a right to justice (access to justice), mediation and conciliatory proceedings; a right to restitution or compensation for damage. ${ }^{39}$ On principle, representatives of the judicial authorities, the Police, health and social services are obligated to observe the above rules. In Polish legal doctrine, it is especially stressed that a victim of crime should receive a dignified hearing in criminal proceedings, and also he or she should receive legal, material, psychological and social aid. Also, a victim should have a right to safety and protection of family and private life. All these rules adopted in Polish legislation are the result of international and European criminal justice policies. Of particular importance is implementation of the Victims' Directive, and also Directive on the European protection order. ${ }^{40}$ The crime victims' approach has lead to establishing State Compensation for Victims of Certain Intentional Offences; ${ }^{41}$ the Crime Victims Support Network; ${ }^{42}$ Victim Assistance Fund and Post-penitentiary Assistance Fund - commonly called the 'Justice

39 Karta praw ofiary, http://www.wroclaw.pa.gov.pl/pokrzywczeni-podjrzani/kartapraw-ofiary (accessed: 1.10.2019).

40 Respectively: Act of 28 November 2014 on victim and witness protection of and support, (Journal of Laws 2015, item 21); Chapter 66j and 66k of the Polish Code of Criminal Procedure.

41 "Act on State Compensation for Victims of Certain Intentional Offences of 7 July 2005," Journal of Laws 2016, no. 325.

42 https://pk.gov.pl/dzialalnosc/pokrzywdzeni-przestepstwem/pokrzywdzeni-przestepstwem/ (accessed: 1.10.2019); http://www.hfhr.pl/wp-content/uploads/2017/04/ INTERNET_ENG_pokrzywdzeni-podejrzani.pdf (accessed: 1.10.2019); see further: C. Kulesza, Fair trial for a victim of crime?: European standards and Polish experience, https://www.researchgate.net/publication/328602846_Fair_trial_for_a_victim_of_ crime__European_standards_and_Polish_experience (accessed: 1.10.2019). 
Fund'. ${ }^{43}$ Poland has taken actions to implement the principles arising from the Victims' Directive primarily through the adoption of the Act on victim and witness protection of and support (2015) and introducing amendments to the Code of Criminal Procedure and the Penal Code. Also important are the guidelines of the Prosecutor General to protect individual categories of crime victims, covered in such acts as on conducting the proceedings on hate crime (2014); ${ }^{44}$ regarding the procedural rules in cases of rape crime (2015) ${ }^{45}$ and domestic violence (2016). ${ }^{46}$

The Act on victim and witness protection of and support introduced significant changes in the scope of protection of persons, including issues related to the obligation of instructing the victim of crime about his or her procedural rights. However, there are some critical views about the implementation of the Victims' Directive into the Polish legal order, namely that it has been only partly implemented. Specifically, the Ombudsman $(2017)^{47}$ expressed his doubts as to whether or not this Directive was fully implemented into the Polish legal order, noting, inter alia, that personal characteristics of a victim are not explicitly mentioned in the provisions implementing the directive, which should always be considered when assessing the specific needs of that person. Furthermore, Article 3 of the Directive formulates the obligation of the State to assist victims of crime

43 Article 43 of the Polish Executive Penal Code. Regulations on Victim Assistance Fund and Post-penitentiary Assistance Fund: commonly called 'Justice Fund' (Journal of Laws 2017, item 1760).

44 Wytyczne Prokuratora Generalnego z dnia 26 lutego 2014 roku w zakresie prowadzenia postępowań o przestępstwa z nienawiści, https://pk.gov.pl/dzialalnosc/wytycznei-zarzadzenia/wytyczne-i-zarzadzenia/ (accessed: 3.10.2019).

45 Wytyczne Prokuratora Generalnego z dnia 18 grudnia 2015 roku dotyczące zasad postępowania w sprawach o przestępstwo zgwałcenia, https://pk.gov.pl/dzialalnosc/ wytyczne-i-zarzadzenia/wytyczne-i-zarzadzenia/ (accessed: 3.10.2019).

46 Wytyczne Prokuratora Generalnego z dnia 22 lutego 2016 roku dotyczące zasad postępowania powszechnych jednostek organizacyjnych prokuratury w zakresie przeciwdziałania przemocy w rodzinie, https://pk.gov.pl/dzialalnosc/wytyczne-i-zarzadzenia/wytyczne-i-zarzadzenia/ (accessed: 3.10.2019).

47 Letter from the Ombudsman Adam Bodnar XI.518.39.2017. to the Minister of Justice - the Prosecutor General, https://www.rpo.gov.pl/sites/default/files/Wystąpienie $\% 20$ do $\% 20 \mathrm{MS} \% 20 \mathrm{w} \% 20$ sprawie $\% 20$ implementacji\%20dyrektywy $\% 20$ ofiarowej $\% 20$ 10.08.2017.pdf (accessed: 2.10.2019). 
to understand and be understood from the first contact with the competent authority.

However, the Ombudsman points out that there are no systemic solutions in the Polish criminal procedure to ensure the enforcement of this obligation. Only the guidelines of the Prosecutor General (2016) on the procedural rules of common organisational units of the prosecutor's office for preventing domestic violence ${ }^{48}$ introduced the obligation to properly inform the victim in a comprehensive and understandable way about the granted right as a party at the stage of preparatory proceedings. He also argues that some problems may occur related to the right to an interpreter. According to him the practice shows that often, judicial authorities try to ensure communication with the victim using an English interpreter. It is pointed out that there are practical difficulties in having real access to the assistance of an interpreter, especially for deaf people.

What is more, "The letter of victims" rights" is delivered in an incomprehensible (inaccessible) language to the average person. Another question may be concerned with cross-border situations. Many notifications in the event of the offences committed on the territory of EU Member States other than Poland are not accepted by Polish law enforcement authorities at all (verbal refusals), or decisions on refusal to initiate or discontinue the proceedings are issued in these cases (e.g. due to the fact that the perpetrator is not subject to the jurisdiction of Polish criminal courts). Also, one should pay attention to Article 20 of the Directive that is of particular importance for victims of sexual crimes, in a sense of the need to take action to ensure more effective protection of their fundamental freedoms and rights. Another indicated issue is that under Polish laws there is no order to carry out an individual assessment of the needs for the protection of the crime victim.

Such a situation may create some potential risk that an individual assessment of the specific needs of the victim will not be carried out in each case, and therefore the rights of victims may not be sufficiently protected in this respect. In relation to a psychologist's participation in the hearing,

48 Wytyczne Prokuratora Generalnego z dnia 22 lutego 2016 roku dotyczące zasad postępowania powszechnych jednostek organizacyjnych prokuratury w zakresie przeciwdziałania przemocy w rodzinie, https://pk.gov.pl/dzialalnosc/wytyczne-i-zarzadzenia/ wytyczne-i-zarzadzenia/ (accessed: 3.10.2019). 
it is said that his/her role is rather to determine whether the state of the witness can affect the evidential value of his/her testimony, not to assist the victim as such. Also, there is no provision that would guarantee the right to be questioned, if possible, by persons of the same sex as the victim. The next issue, of no lesser importance is the need to create appropriate and friendly conditions for interviewing children in order to avoid repeated interrogations. A special mode of interrogation applies to children who are under 15 at the time of their hearing, while the Victims' Directive indicates that every child is a person under 18 years old. ${ }^{49}$

\section{Conclusions}

The Victims' Directive undoubtedly inaugurates a relevant change in criminal justice through introducing a system of minimum standards on the rights, support and protection for victims of crimes and their participation in criminal proceedings, without prejudicing the rights of the offender. However, there may be an arising question about a right to a fair trial in the context of the rights of the accused or suspects, in order to ensure fairness of criminal proceedings. According to Andre Klip, the victims' increasing role in criminal proceedings may lead to more time consuming criminal trials. In other words, the question arises of fairness to the victim and to the accused, especially in the sense of reasonable time of a trial; the strengthening role of the victim may prolong the criminal proceedings. ${ }^{50}$ Another issue is raised by Gabrio Forti, who pays attention that within the scope of the Victims' Directive there is a relevant group of victims who have not yet received enough consideration, and whose access to justice may be at stake. He means the victims of corporate crimes, and particularly of corporate violence : those criminal offences committed by corporations in the course of their legitimate activities, which result in harm to natural persons' crimes. $^{51}$

49 Letter from the Ombudsman Adam Bodnar XI.518.39.2017. to the Minister of Justice - the Prosecutor General.

50 A. Klip, op. cit., pp. 33-334.

51 G. Forti, "Introduction," [in:] Victims and Corporations..., pp. 1-13; S. Manacorda, I. Gasparini, “Corporate victims in European Union Law: The 'Sound of Silence,'” [in:] ibid., p. 89-111. 
Despite these comments, one should admit that factually the Victims' Directive is an important legal tool strengthening to a large extent the status of victims in the course of criminal proceedings. It is commonly argued that judicial authorities of Member States should place trust in the criminal justice systems of other Member States. Thus, for the purpose of enhancing mutual trust among EU Member States, it is important that the established standards for procedural (legal) rights of victims should be properly implemented and applied in their national criminal justice systems. Specifically that pursuant to the norms of international human rights law everyone deserves a fair trial, conducted in compliance with the established minimum standards. However, enjoying the rights granted to victims through introducing common human standards into criminal justice depends not only upon international or national policies, but first of all on the goodwill of the police and judicial authorities as well as all social agencies which may be involved in the assistance programmes.

In recent years, the Polish legislator has made much effort to adjust the national criminal justice system to international and European standards in protecting crime victims' rights, and at the same time strengthening the status of crime victims in criminal proceedings. The adopted legal solutions are compatible with international and European trends aiming to enhance the status of the victim in criminal proceedings. Actually, as a result of implementing Union norms, the injured person: a victim of crime, takes a relatively strong position in the course of criminal proceedings under Polish laws.

\section{References}

\section{Literature}

Aertsen I., "Victims' Rights: an Overview," [in:] Rights of Victims, Challenges for Corporations: Project's First Findings, ed. C. Mazzucato, Milano 2016, pp. 2-7, http:// www.victimsandcorporations.eu/.

Bassiouni M. Cherif, "International Recognition of Victim's Rights," [in:] International Criminal Law, (third edition) vol. 1, ed. M. Cherif Bassiouni, Leiden 2008, pp. 636701.

Blackstock J., Protecting Victims: EU competences and mechanisms for safeguards. Paper presented at the Symposium: 'Legal Perspectives on the Victims', Nottingham 
Trent University, 19 December 2012, http://2bquk8cdew6192tsu41lay8t.wpengine. netdna-cdn.com/wp-content/uploads/2015/02/Protecting-Victims-EU-Competencesand-mechanisms-for-safeguards.pdf.

Dearing A., Justice for Victims of Crime: Human Dignity as the Foundation of Criminal Justice in Europe, Cham 2017.

Fichera M., "The Status of the Victim in the European Union Criminal Law," Eucrim 2011, no. 2, pp. 79-81.

Groenhuijsen M.S., Pemberton A., "Developing victims' rights within the European Union. Past, present and future," [in:] Victimology and human security: New horizons, eds. H. Morosawa, J.J.P Dussich, G.F. Kirchoff, Nijmegen 2012, pp. 535-559.

Groenhuijsen M.S.,Pemberton A., "The EU Framework Decision for Victims of Crime: Does Hard Law Make a Diff erence?," Eur J.Cr.L.Cr.J 2009, no. 17, pp. 43-59.

Human Rights in European Criminal Law: New Developments in the European Legislation and Case Law After the Lisbon Treaty, ed. S. Ruggeri, Heidelberg 2015.

Klip A., European Criminal Law, Cambridge 2016.

Kulesza C., Fair trial for a victim of crime? - European standards and Polish experience, https://www.researchgate.net/publication/328602846_Fair_trial_for_a_victim of_crime_-_European_standards_and_Polish_experience.

Maff ei S., The European Right to Confrontation in Criminal Proceeding. Absent, Anonymous and Vulnerable Witnesses, Groningen 2006.

Mancuso E.M., "Victims' Participation in Criminal Proceedings," [in:] Rights of Victims, Challenges for Corporations: Project's First Findings, ed. C. Mazzucato, Milano 2016, pp. 2-3, 27, http://www.victimsandcorporations.eu/.

Mazzucato C., "Victims in the European Union and the Directive 2012/29/EU," [in:] Rights of Victims, Challenges for Corporations: Project's First Findings, ed. C. Mazzucato, Milano 2016, pp. 18-19, http://www.victimsandcorporations.eu/.

Mitsilegas V., EU criminal law after Lisbon: Rights, Trust, the Transformation of Justice in Europe, Oxford-Portland-Oregon 2016.

Mujuzi J.D., "Victim participation in the criminal justice system in the European Union through private prosecutions: Issues emerging from the jurisprudence of the European Court of Human Rights," European Journal of Crime Criminal Law and Criminal Justice 24, 2016, no 2, pp. 107-134, https://repository.uwc.ac.za/xmlui/bitstream/handle/10566/3832/Mujuzi_Victim-participation_2016.pdf?sequence=1\&isAllowed=y.

The New Faces of Victimhood: Globalisation, Transnational Crimes and Victims Rights, eds. R. Letschert, J. Van Dijk, Dordrecht 2011.

Protecting Vulnerable Groups. The European Human Rights Framework, eds. F. Ippolito, S. Sanchez Iglesias, Oxford-Portland 2015.

Trechsel St., Summers Sarah J., Human Rights in Criminal Proceedings, Oxford 2005. Wemmers J-A., "Victims' experiences in the criminal justice system and their recovery from crime," International Review of Victimology 19, 2013, no. 5, pp. 221-233.

Van der Aa S. et al., Project Victims in Europe: Implementation of the EU Framework Decision on the standing of victims in the criminal proceedings in the Member States of the European Union, Lisbon 2009, APAV, https://cris.maastrichtuniversity.nl/por- 
tal/en/publications/project-victims-in-europe-implementation-of-the-eu-frameworkdecision-on-the-standing-of-victims-in-criminal-proceedings-in-the-member-statesof-the-european-union(c0faf87e-e27c-43a1-9e11-5bb82466eb0c)/export.html.

Victims and Corporations: Legal Challenges and Empirical Findings, eds. G. Forti, C. Mazzucato, A. Visconti, S. Giavazzi, Milano-Padova 2018, https://asgp.unicatt. it/asgp-VictimsCorporations_Ebook_2018.pdf.

Victims and Criminal Justice. European Standards and National Good Practices, ed. L. Luparia, Padova 2015.

Victims and Restorative Justice, eds. I. Vanfraechem, D. Bolivar, I. Aertsen, London 2015.

\section{Documents}

Act of 28 November 2014 on victim and witness protection of and support (Journal of Laws 2015, item 21); Chapter 66j and 66k of the Polish Code of Criminal Procedure. Act on State Compensation for Victims of Certain Intentional Off ences of 7 July 2005 (Journal of Laws 2016, no. 325).

Council Framework Decision of 15 March 2001 on the standing of victims in criminal proceedings, OJ L 82, 22.03.2001.

DG Justice Guidance Document of December 2013 related to the transposition and implementation of Directive 2012/29/EU of the European Parliament and of the Council of 25 October 2012 establishing minimum standards on the rights, support and protection of victims of crime, and replacing Council Framework Decision 2001/220/ JHA, http://ec.europa.eu/justice/criminal/files/victims/guidance_victims_rights_directive_en.pdf (accessed: 25.12.2019).

Directive 2004/80/EC relating to compensation to crime victims, OJ L 261, 6.08.2004.

Directive 2011/36/EU of the European Parliament and of the Council of 5 April 2011 on preventing and combating traffi cking in human beings and protecting its victims, and replacing Council Framework Decision 2002/629/JHA, OJ L 101, 15.04.2011.

Directive 2012/29/EU of the European Parliament and of the Council of 25 October 2012 establishing minimum standards on the rights, support and protection of victims of crime, and replacing Council Framework Decision 2001/220/JHA, OJ L 315, 14.11.2012.

Directive 2014/41/EU of the European Parliament and of the Council of 3 April 2014 regarding the European Investigation Order in criminal matters, OJ L 130, 1.05.2014. http://www.hf hr.pl/wp-content/uploads/2017/04/INTERNET_ENG_pokrzywdzeni-podejrzani.pdf (accessed: 1.10.2019).

Karta praw ofiary, http://www.wroclaw.pa.gov.pl/pokrzywczeni-podjrzani/karta-prawofiary (accessed: 1.10.2019).

Letter from the Ombudsman Adam Bodnar XI.518.39.2017. to the Minister of Justice the Prosecutor General, https://www.rpo.gov.pl/sites/default/files/Wystąpienie\%20 do $\% 20 \mathrm{MS} \% 20 \mathrm{w} \% 20$ sprawie $\% 20 \mathrm{implementacji} \% 20$ dyrektywy $\% 20$ ofiarowej $\%$ 2010.08.2017.pdf (accessed: 2.10.2019).

https://pk.gov.pl/dzialalnosc/pokrzywdzeni-przestepstwem/pokrzywdzeni-przestepstwem/ (accessed: 1.10.2019).

Nowa Kodyfikacja Prawa Karnego 52, 2019

(C) for this edition by CNS 
Recommendation CM/Rec (2012)2 of the Committee of Ministers to member States on the participation of children and young people under the age of 18 (Adopted by the Committee of Ministers on 28 March 2012 at the 1138th meeting of the Ministers' Deputies), https://rm.coe.int/168046c478 (accessed: 19.12.2017).

Report (2014): Victims of crime in the EU: the extent and nature of support for victims, FRA-European Union agency for Fundamental Rights, https://fra.europa.eu/sites/ default/fi les/fra-2015-victims-crime-eu-support_en_0.pdf (accessed: 30.09.2019).

Report on the standing and rights of victims in criminal proceedings, prepared by $\mathrm{Mr}$. Brano Bohacik, European Committee on Crime Problems (CDPC), Strasbourg, 20 September 2010, https://rm.coe.int/168070c7e4 (accessed: 30.09.2019).

Rights of the victim, http://ec.europa.eu/justice/criminal/victims/rights/index_en.htm (accessed: 19.12.2017).

Wytyczne Prokuratora Generalnego z dnia 26.022014 w zakresie prowadzenia postępowań o przestępstwa z nienawiści, https://pk.gov.pl/dzialalnosc/wytyczne-i-zarzadzenia/wytyczne-i-zarzadzenia/ (accessed: 3.10.2019).

Wytyczne Prokuratora Generalnego z dnia 18.12.2015 dotyczące zasad postępowania w sprawach o przestępstwo zgwałcenia, https://pk.gov.pl/dzialalnosc/wytyczne-izarzadzenia/wytyczne-i-zarzadzenia/ (accessed: 3.10.2019).

Wytyczne Prokuratora Generalnego z dnia 22.02.2016 dotyczące zasad postępowania powszechnych jednostek organizacyjnych prokuratury w zakresie przeciwdziałania przemocy w rodzinie, https://pk.gov.pl/dzialalnosc/wytyczne-i-zarzadzenia/wytyczne-i-zarzadzenia/ (accessed: 3.10.2019).

Victim Support Europe (2013) Handbook for Implementation of Legislation and Best Practice for Victims of Crime in Europe, http://victimsupporteurope.eu/activeapp/ wp-content/files_mf/1385974688NewVersionVSEHandbookforImplementation.pdf (accessed: 30.09.2019).

\section{Jurisprudence}

Case Number C-79/11, Criminal proceedings against Maurizio Giovanardi and Others, Date of the judgement 2012-07-12, Court of Justice (ECJ).

Criminal proceedings against Maria Pupino, Case Number C-105/03, Date of the judgement 16-06-2005, Court of Justice (ECJ).

Criminal proceedings against Giovanni Dell'Orto, Case Number C-467/05, Date of the judgement 2007-06-28, Court of Justice (ECJ).

Criminal proceedings against Emil Eredics and Mária Vassné Sápi. Case Number C-205/09, Date of the judgement 2010-10-21, Court of Justice(ECJ).

Criminal proceedings against X C-507/10, Case Number C-507/10, Date of the judgement 2011-12-21, Court of Justice (ECJ).

Ernst and Others v. Belgium, 33400/96, 15 July 2003.

Gorou v. Greece (N²) [GC], 12686/03, 20 March 2009.

Gueye and Salmerón Sánchez, Joined cases C-483/09 and C-1/10, Date of the judgement 2011-09-15, Court of Justice (ECJ). 
Győrgy Katz v István Roland Sós, Case number C-404/07, Date of the judgement 200810-09, Court of Justice (ECJ).

Perez v. France [GC], 47287/99, 12 February 2004.

Sottani v. Italy, 26775/02, 24 February 2005.

\section{Summary}

In recent years, more and more attention has been focused on the interests of crime victims, including their enlarging role in criminal proceedings. The procedural rights of, and assistance to, victims of crime are gradually becoming essential aspects of contemporary criminal justice systems. In the transnational context at the European Union level, the Directive 2012/29/EU establishing minimum standards on the rights, support and protection of victims of crime is of significant importance as this legal instrument contains some concrete rights for victims of crime and clearer obligations imposed on the competent national authorities. Unfortunately, in many EU Member States the regulations on the standing victims in criminal proceedings are not properly or fully implemented into national legislation. This paper aims to give some insight to the provisions of the EU Victims' Directive, and also the issue regarding its transposition into the Polish legal order.

Keywords: Crime victims' rights, EU criminal justice, human rights in criminal justice 